\title{
Anti-wear and Hardness Values of Functional Value-Added Zn-ZnO-Rice Husk Ash Composite Coating of Mild Steel
}

\author{
Daniel-Mkpume Cynthia Chikodi ${ }^{1}$, Obikwelu Daniel Oray Nnamdi ${ }^{1}$, Aigbodion Victor Sunday 1,2,3* $^{*}$ \\ ${ }^{1}$ Department of Metallurgical and Materials Engineering, University of Nigeria, Nsukka 410001, Nigeria \\ ${ }^{2}$ Faculty of Engineering and Built Environment, University of Johannesburg, Auckland Park 534, South Africa \\ ${ }^{3}$ Africa Centre of Excellence, ACESPED University of Nigeria, Nsukka 410001, Nigeria
}

Corresponding Author Email: victor.aigbodion@unn.edu.ng

https://doi.org/10.18280/rcma.310104

Received: 20 August 2020

Accepted: 28 January 2021

\section{Keywords:}

anti-wear, hardness, morphology, composite coating, electrodeposition

\begin{abstract}
This paper presents the anti-wear and hardness values of electrodeposited $\mathrm{Zn}-\mathrm{ZnO}$ XRHA composite coating. Chloride-based bath was employed for the deposition bath. The deposition parameters were $0 \mathrm{~g}, 10 \mathrm{~g}$ and $20 \mathrm{~g}$ rice husk ash (RHA) particulate loading, 15 minutes deposition, $1.4 \mathrm{~A}$ current, $400 \mathrm{rpm}$ stirring rate and $75^{\circ} \mathrm{C}$ bath temperature. The composition, morphology, occurred phases, hardness and wear resistance for the RHA, mild steel substrate and developed coatings were studied. Equipment used for analyzing the coatings properties were $\mathrm{x}$-ray fluorescence spectrometer, scanning electron microscope (SEM) with attached energy dispersive spectrometer (EDS), X-ray diffractometer (XRD), EMCO Test Dura-scan microhardness tester and CERT UMT-2 tribological tester. Results showed that the $\mathrm{Zn}-\mathrm{ZnO}-20 \mathrm{RHA}$ coated substrate had the highest hardness result toping the bare substrate by about $170 \%$ increment value. The trend of the wear loss for the developed $\mathrm{Zn}-\mathrm{ZnO}$-XRHA descended relative to increased particulate loading
\end{abstract}

\section{INTRODUCTION}

Expressly, it is highly motivating in the globe of research to ascertain a leeway for surface enhancement of mild steel (MS) for improved surface characteristics employing a downtrodden material such as rice husk (RH) [1]. This indeed is a real time value addition, as it regenerates waste into a resourceful engineered material - a novelty indeed. Mild steel being an ingenious structural engineering piece, remains vastly indomitable [2]. This feasibility stems from the mechanical potentials of steel coupled with its low cost and availability [3]. Particulates incorporation into coatings produced on various substrate materials via diverse techniques comprising chemical vapour deposition [4], electrodeposition [3], hot dipping [5], plasma spray, physical vapour deposition [6], spray pyrolysis [7-9] and thermal spraying [10] have proven credibility on diverse properties enhancement. In comparison with all these techniques, electrodeposition is devoid of sophistication, consumes minimal energy, enables coating of intricate parts and remains cost effective. Also, the efficiency of thin film production is optimally achieved in this case [11]. It is evident from researches that ceramic particles of aluminium silicate $\left(\mathrm{Al}_{2} \mathrm{SiO}_{4}\right)$ [12], alumina $\left(\mathrm{Al}_{2} \mathrm{O}_{3}\right)$ [13], silica $\left(\mathrm{SiO}_{2}\right)$ [14], silicon carbide $(\mathrm{SiC})$ [15], titania $\left(\mathrm{TiO}_{2}\right)$ [13], yttria $\left(\mathrm{Y}_{2} \mathrm{O}_{3}\right)[16]$, zirconia $\left(\mathrm{ZrO}_{2}\right)$ [17], graphene oxide $(\mathrm{GO})$ [18], fullerene $\left(\mathrm{C}_{60}\right)$ [19] and niobium oxide $\mathrm{Nb}_{2} \mathrm{O}$ [20] have served as additives in zinc-based electrodeposited coatings. These incorporations have significantly made-up for the shortcomings of zinc. Consequently, development of new surface engineering materials with commendable microhardness, wear resistance and thermal properties has been achieved [14]. Hence, this work anchors on finding the effect of RHA on the microhardness, wear resistance and thermal properties of $\mathrm{Zn}-\mathrm{ZnO}-\mathrm{RHA}$ coated mild steel for defence application obviously not reported prior to this work.

\section{MATERIALS AND METHOD}

\subsection{RHA preparation}

RH sample collected from a rice mill was washed in $0.1 \%$ $\mathrm{NaOH}$ and thoroughly rinsed in a trough of distilled water. The washed sample was sun-dried at ambient temperature range of $27-29^{\circ} \mathrm{C}$. Subsequently, incineration of the sample in the open air was done. Incinerated sample was then put into the Carbolite furnace at $1200^{\circ} \mathrm{C}$ for 10 hours and furnace-cooled for ash formation. The resulting ash sample was pulverized in a ball mill for 6 hours to ensure particulate homogeneity [21].

\subsection{Substrate preparation}

The steel substrate which was the cathode material was sectioned to the dimension $50 * 40 * 20 \mathrm{~mm}$ with its elemental composition presented in Table 1 . The anode material was pure zinc sheet with $99.99 \%$ purity. The mild steel substrate was prepared by mechanically grinding the surface using emery paper in a succession of fineness, P60, P80, P150, P220, P350, P600, P800, P1000 and P1200 grits. Subsequently, the substrate was degreased in acetone, thoroughly rinsed in distilled water and dried with a hand dryer [21]. 


\subsection{Bath preparation}

The bath composed of distilled water and annular grade chemicals comprising zinc chloride $100 \mathrm{~g} / \mathrm{L}$, zinc oxide $15 \mathrm{~g} / \mathrm{L}$, boric acid $10 \mathrm{~g} / \mathrm{L}$, potassium oxide $40 \mathrm{~g} / \mathrm{L}$, sodium chloride 5 $\mathrm{g} / \mathrm{L}$, thiourea $10 \mathrm{~g} / \mathrm{L}$ and glycine $10 \mathrm{~g} / \mathrm{L}$ prepared at room temperature 24 hours prior deposition. The blend of chemicals was heated at $75^{\circ} \mathrm{C}$ at a constant stirring rate of $400 \mathrm{rpm}$ for 30 minutes to establish the bath temperature and homogeneity per deposition with RHA additive incorporated prior to deposition proper [21].

\subsection{Deposition setup}

The deposition was done using the setup shown in Fig 1 and the produced coated substrate shown. The choice of the varied deposition parameter stems from the literature [16, 22]. Mild steel (MS) substrate as cathode material and the zinc as the anode material were duly connected to the rectifier and immersed into the deposition bath setting the stirring rate to $400 \mathrm{rpm}$, temperature to $75^{\circ} \mathrm{C}$ and time to $15 \mathrm{mins}$. When the bath temperature was attained the deposition was initiated by switching on the rectifier. At the termination of the deposition process the samples produced shown in Figure 1 were rinsed in a trough with distilled water and dried for ten minutes using a hand dryer [21].

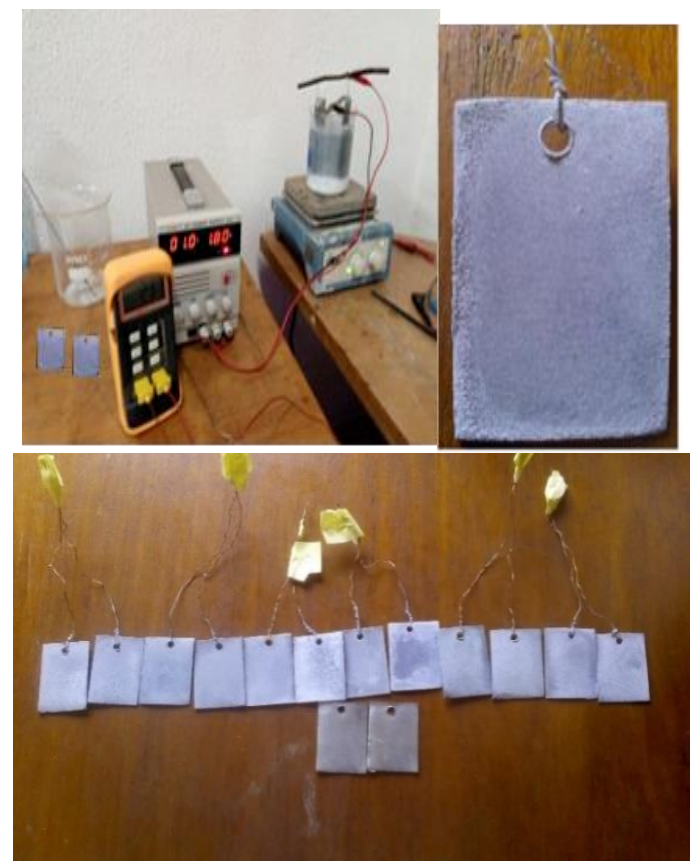

Figure 1. The deposition setup and coated sample [21]

\subsection{Characterization and testing of RHA and coating}

The phases and constituents of the prepared RHA were determined via XRD and XRF respectively. The results are shown in Figure 2 and Table 2 respectively. Figure 3 show the XRD results of the developed coatings. VEGA3 TESCAN, scanning electron microscope with operational EDS was employed for the characterization of the RHA and the developed coatings and the micrographs are shown in Figure 4 and Figure 5 [21]. The mechanical tests considered in this research were microhardness as well as wear resistance. The microhardness test was aided by a diamond pyramid indenter EMCO Test Dura-scan microhardness tester at $10 \mathrm{~g}$ load for
20 s span across the coating. The experiment was run in triplicate per sample. The average results are revealed in Figure 6 [21].

The CERT UMT-2 tribological tester was used for the wear test at an ambient temperature of $25^{\circ} \mathrm{C}$. The slip test was performed on a sample sized $2 \mathrm{~cm}$ by $1.5 \mathrm{~cm}$, with a load of $15 \mathrm{~N}$, constant speed of $5 \mathrm{~mm} / \mathrm{s}$ and displacement range of 3 $\mathrm{mm}$ in 3 minutes. The meter body used for the inspection of the wear behaviour of the developed coating was a steel ball [21]. The wear loss result and that of the friction coefficient are shown in Figure 7. The optical microscopy assessment of the wear tracks is shown in Figure 8.

\section{RESULTS AND DISCUSSION}

3.1 Atomic absorption spectrometry (AAS) and x-ray fluorescence (XRF) spectrophotometry assessment

In Table 1, the composition of the MS substrate material via AAS technique confirms it to be mild steel owing to the carbon content of $0.15(\mathrm{wt} \%)$. The entire constituents compare with mild steel for pipeline application [2]. The compositional constituents of RHA via XRF are presented in Table 2. 98.23 $\mathrm{wt} \%$ silica in the analysis shows the prominence of silica as the major constituent coexisting with other minor constituents and stands efficacious in exhibiting its known properties as a coating material.

Table 1. Composition of the substrate material via AAS

\begin{tabular}{cc}
\hline Elements & Composition (wt\%) \\
\hline Carbon & 0.150 \\
Manganese & 0.590 \\
Phosphorus & 0.029 \\
Sulphur & 0.032 \\
Silicon & 0.230 \\
Iron & 98.969 \\
\hline
\end{tabular}

In Table 2, the compositional constituents of RHA via XRF are presented. This shows the prominence of Silica $(98.23 \mathrm{wt} \%)$ as the major constituent coexisting with other minor constituents.

Table 2. Composition of the RHA via XRF

\begin{tabular}{|c|c|}
\hline Elements & Composition (wt\%) \\
\hline $\begin{array}{c}\mathrm{Al}_{2} \mathrm{O}_{3} \\
\text { Carbon }\end{array}$ & 0.21 \\
\hline $\mathrm{C}_{60}$ & 0.28 \\
\hline $\mathrm{CaO}$ & 0.36 \\
\hline $\mathrm{Fe}_{2} \mathrm{O}_{3}$ & 0.18 \\
\hline $\mathrm{K}_{2} \mathrm{O}$ & 0.34 \\
\hline $\mathrm{Mn}_{3} \mathrm{O}_{4}$ & 0.03 \\
\hline $\mathrm{MgO}$ & 0.14 \\
\hline $\mathrm{P}_{2} \mathrm{O}_{5}$ & 0.07 \\
\hline $\mathrm{SO}_{3}$ & 0.1 \\
\hline $\mathrm{TiO}_{2}$ & 0.002 \\
\hline $\mathrm{Y}_{2} \mathrm{O}_{3}$ & 0.003 \\
\hline $\mathrm{ZnO}$ & 0.01 \\
\hline $\mathrm{SiO}_{2}$ & 98.23 \\
\hline
\end{tabular}

\subsection{X-ray diffractometry (XRD) assessment}

The XRD assessment of the RHA particulate shown in Figure 2, Table 3 and Table 4 epitomize peaks of $\mathrm{Al}_{2} \mathrm{SiO}_{5}$ 
(Aluminum Silicate), $\mathrm{SiO}_{2}$ (Silicon Oxide and Quartz), and C60 (Carbon). The XRD spectrum of the RHA showed silicon oxide as the major amorphous phase of silica.

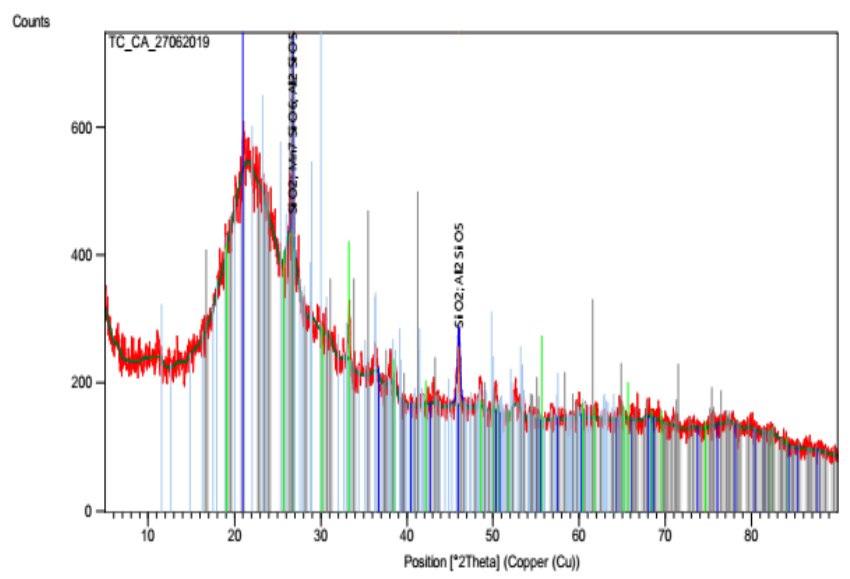

Figure 2. XRD assessment of the RHA particulate
Figure 3 presents the XRD assessment of the substrate and the developed $\mathrm{Zn}-\mathrm{ZnO}-0 \mathrm{RHA}, \mathrm{Zn}-\mathrm{ZnO}-10 \mathrm{RHA}$, and $\mathrm{Zn}$ $\mathrm{ZnO}-20 \mathrm{RHA}$ coatings. The XRD of the substrate material proves it to be steel with the presence of $\mathrm{Fe}$ and $\mathrm{Fe}_{3} \mathrm{C}$ diffraction peaks. The features of the pattern of the XRD of $\mathrm{Zn}$-ZnO-XRHA complex coating are quite similar. With increase in the particulate addition of RHA, the appearance of more phases and diffraction peaks occurred. The emerged prominent phases on the coating material are shown in Table 5 and Table 6. Outstanding were the Zinc (Zn), Silicon Oxide $\left(\mathrm{SiO}_{2}\right)$, Aluminum Oxide Carbide (A12OC), Zinc Aluminum Silicate $\left(\mathrm{Zn}_{2} \mathrm{Al}_{4} \mathrm{Si}_{5} \mathrm{O}_{18}\right)$ and $\mathrm{Zinc}$ Carbide $\left(\mathrm{ZnC}_{8}\right)$ which belong to the Hexagonal Crystal System (CS). Also, there exist phases of Aluminum Oxide $\left(\mathrm{Al}_{2} \mathrm{O}_{3}\right)$ and Zinc Silicate $\left(\mathrm{Zn}_{2} \mathrm{SiO}_{4}\right)$ belonging to the Monoclinic and Orthorhombic Crystal systems respectively. The developed phases synchronized with other mono-constituents researches where one component was incorporated into the zinc to produce dependable coating [7-10]. From the developed the multiphase RHA incorporated into the coating places it on the research pinnacle.

Table 3. XRD results of matched peaks for RHA

\begin{tabular}{ccccc}
\hline Pos. $\left[{ }^{\circ} \mathbf{2 T h}\right.$.] & Height [cts] & d-spacing [̊] & Rel. Int. [\%] & Matched by \\
\hline 12.4276 & 5308.64 & 7.12258 & 100.00 & $34-1382$ \\
20.9252 & 1931.90 & 4.24539 & 36.39 & $83-2466 ; 20-0258$ \\
24.9460 & 2934.45 & 3.56949 & 55.28 & $80-2147$ \\
26.6940 & 5153.47 & 3.33959 & 97.08 & $88-0893 ; 83-2466$ \\
35.0375 & 307.99 & 2.56110 & 5.80 & $77-2135 ; 20-0258 ; 80-2147$ \\
38.4923 & 541.57 & 2.33882 & 10.20 & $88-0893$ \\
50.1980 & 436.42 & 1.81746 & 8.22 & $88-0893 ; 83-2466$ \\
55.2217 & 204.57 & 1.66342 & 3.85 & $88-0893 ; 83-2466$ \\
59.9611 & 372.52 & 1.54150 & 7.02 & $88-0893 ; 77-2135 ; 80-2147$ \\
\hline
\end{tabular}

Table 4. XRD results indicating the salient phases for RHA

\begin{tabular}{ccccc}
\hline Visible & Ref. Code & Score & Compound Name & Chemical Formula \\
\hline$*$ & $88-0893$ & 15 & Sillimanite & $\mathrm{Al}_{2} \mathrm{SiO}_{5}$ \\
$*$ & $83-2466$ & 34 & Quartz, syn & $\mathrm{SiO}_{2}$ \\
$*$ & $76-0931$ & 21 & Silicon Oxide & $\mathrm{SiO}_{2}$ \\
$*$ & $77-2135$ & 17 & Corundum & $\mathrm{Al}_{2} \mathrm{O}_{3}$ \\
$*$ & $20-0258$ & 20 & Carbon & $\mathrm{C}$ \\
$*$ & $80-2147$ & 16 & Silicon Oxide & $\mathrm{SiO}_{2}$ \\
$*$ & $34-1382$ & 16 & Silicon Oxide & $\mathrm{SiO}_{2}$ \\
\hline
\end{tabular}

Table 5. XRD results of matched peaks for coated substrates

\begin{tabular}{ccccc}
\hline Pos. [ ${ }^{\circ}$ 2Th.] & Height [cts] & d-spacing [̊] & Rel. Int. [\%] & Matched by \\
\hline 22.0025 & 383.56 & 4.03990 & 4.07 & $81-0067 ; 50-1496$ \\
28.1962 & 1745.27 & 3.16499 & 18.54 & $81-0067 ; 51-0627 ; 50-1496 ; 32-1456$ \\
32.8433 & 2127.74 & 2.72702 & 22.61 & $36-0148 ; 24-1469$ \\
36.2543 & 5961.33 & 2.47789 & 63.33 & $87-0713 ; 24-1469 ; 51-0627$ \\
38.9959 & 1929.23 & 2.30976 & 20.50 & $87-0713 ; 81-0067 ; 51-0627$ \\
43.2120 & 9412.61 & 2.09367 & 100.00 & $87-0713 ; 81-0067 ; 24-1469 ; 51-0627$ \\
44.6585 & 2341.57 & 2.02917 & 24.88 & $24-1469$ \\
54.3164 & 1440.56 & 1.68899 & 15.30 & $87-0713 ; 32-1456$ \\
58.2878 & 1027.69 & 1.58302 & 10.92 & $81-0067 ; 36-0148 ; 24-1469 ; 50-1496$ \\
70.0825 & 1600.49 & 1.34160 & 17.00 & $87-0713 ; 36-0148$ \\
\hline
\end{tabular}

Table 6. XRD results indicating the salient phases in the coatings

\begin{tabular}{cccc}
\hline Ref. Code & Compound Name & Chemical Formula & Crystal system \\
\hline $87-0713$ & Zinc & $\mathrm{Zn}$ & Hexagonal \\
$81-0067$ & Silicon Oxide & $\mathrm{SiO}_{2}$ & Hexagonal \\
$36-0148$ & Aluminum Oxide Carbide & $\mathrm{Al}_{2} \mathrm{OC}$ & Hexagonal \\
$24-1469$ & Zinc Silicate & $\mathrm{Zn}_{2} \mathrm{SiO}_{4}$ & Orthorhombic \\
$51-0627$ & Zinc Carbide & $\mathrm{ZnC}_{8}$ & Hexagonal \\
$50-1496$ & Aluminum Oxide & $\mathrm{Al}_{2} \mathrm{O}_{3}$ & Monoclinic \\
$32-1456$ & Zinc Aluminum Silicate & $\mathrm{Zn}_{2} \mathrm{Al}_{4} \mathrm{Si}_{5} \mathrm{O}_{18}$ & Hexagonal \\
\hline
\end{tabular}




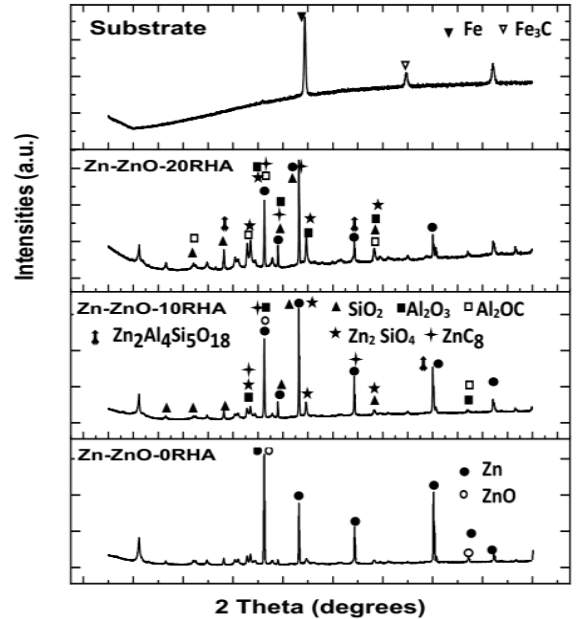

Figure 3. Comparative XRD assessment of the substrate material, Zn-ZnO-0RHA, Zn-ZnO10RHA, and Zn-ZnO20RHA coatings

\subsection{Morphological study}

The morphology in Figure 4, presents a dominantly projected silica structure as established by EDS and XRD as prominent. The EDS also shows the presence of Oxygen $(\mathrm{O})$, Silicon (Si), Carbon (C), Phosphorus(P), Calcium (Ca), Magnesium $(\mathrm{Mg})$ and Potassium $(\mathrm{K})$ with $\mathrm{Si}$ as the main constituent.

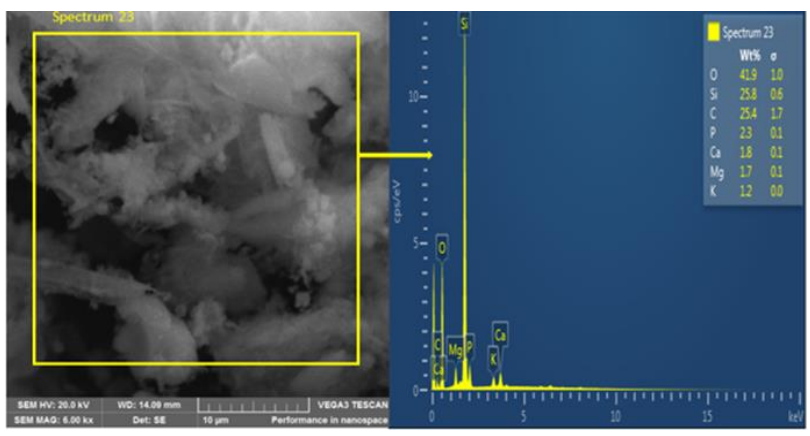

Figure 4. Morphological assessment of the RHA additive

Figure 5 (a) - (d) show the surface morphology of the uncoated steel substrate, $\mathrm{Zn}-\mathrm{ZnO}-0 \mathrm{RHA}, \mathrm{Zn}-\mathrm{ZnO}-10 \mathrm{RHA}$, and $\mathrm{Zn}-\mathrm{ZnO}$-20RHA developed coating on MS substrate with attached EDS. Uniform layer dispersion was achieved in the $\mathrm{Zn}-\mathrm{ZnO}$-XRHA coated substrate which serves as an indication of homogeneous crystallite distribution of the coating on the substrate. In the $\mathrm{Zn}-\mathrm{ZnO}$-XRHA system, it is notable that agglomeration promotes both the effect of particulate deposition and subsequently, sedimentation. Stability is actually obvious with an interlock of the matrix at the interface of $\mathrm{Zn}-\mathrm{ZnO}$-RHA compared to coatings made with 0RHA. The morphological change may be dependent on the change from the preferred orientation of the hard phase RHA composite to a randomly oriented composite deposit [23]. This undeniably promotes enhanced properties.

\subsection{Micro-hardness assessment}

Figure 6 shows the micro-hardness (HVN) result for the developed coatings on the MS substrate. Epitomized in Figure 6, is increased hardness from $61.7 \mathrm{HVN}$ to $166.63 \mathrm{HVN}$ measured laterally on the substrate coated surface. Ample improvement in the microhardness result of developed coatings was observed. The most evident is on the $\mathrm{Zn}-\mathrm{ZnO}-$ 20RHA developed coating. This may be ascribed to the establishment of adherence intermetallic phase as well as the conditioning effect posed by RHA ceramics incorporated into the $\mathrm{Zn}-\mathrm{ZnO}$ binary system. Though the improved microhardness property has been credited to ceramics incorporated composite in the coating, it is notable that the strengthening performance relative to the enhanced microhardness is a function of microstructure inclined to RHA particulate loading [24]. This dispersion of the RHA in the Zn$\mathrm{ZnO}$ binary system clearly impedes the ease of dislocation movement leading to the higher hardness result of developed $\mathrm{Zn}$-ZnO-xRHA composite coating samples. From the developed coatings, the multi-phase RHA incorporated into the coating places it on the research pinnacle.

Qualitatively, the average microhardness values of the developed $\mathrm{Zn}$-ZnO-0RHA composite coating were higher than that of the MS substrate. Hence, it could suggest that RHA portrays a vehement barrier which hampers deformation of the coating matrix and enables improved hardness with increased particulate loading [25]. The $\mathrm{Zn}-\mathrm{ZnO}-20 \mathrm{RHA}$ coated substrate had the highest hardness result toppling the bare substrate by about $170 \%$ increment value. Hence, makes this coating quite commendable. At this juncture, it could be adjudged that the evolution of adhesive characteristics, multiple hard phase formation and grain refinement of the microstructure immensely contributed to the microhardness result.
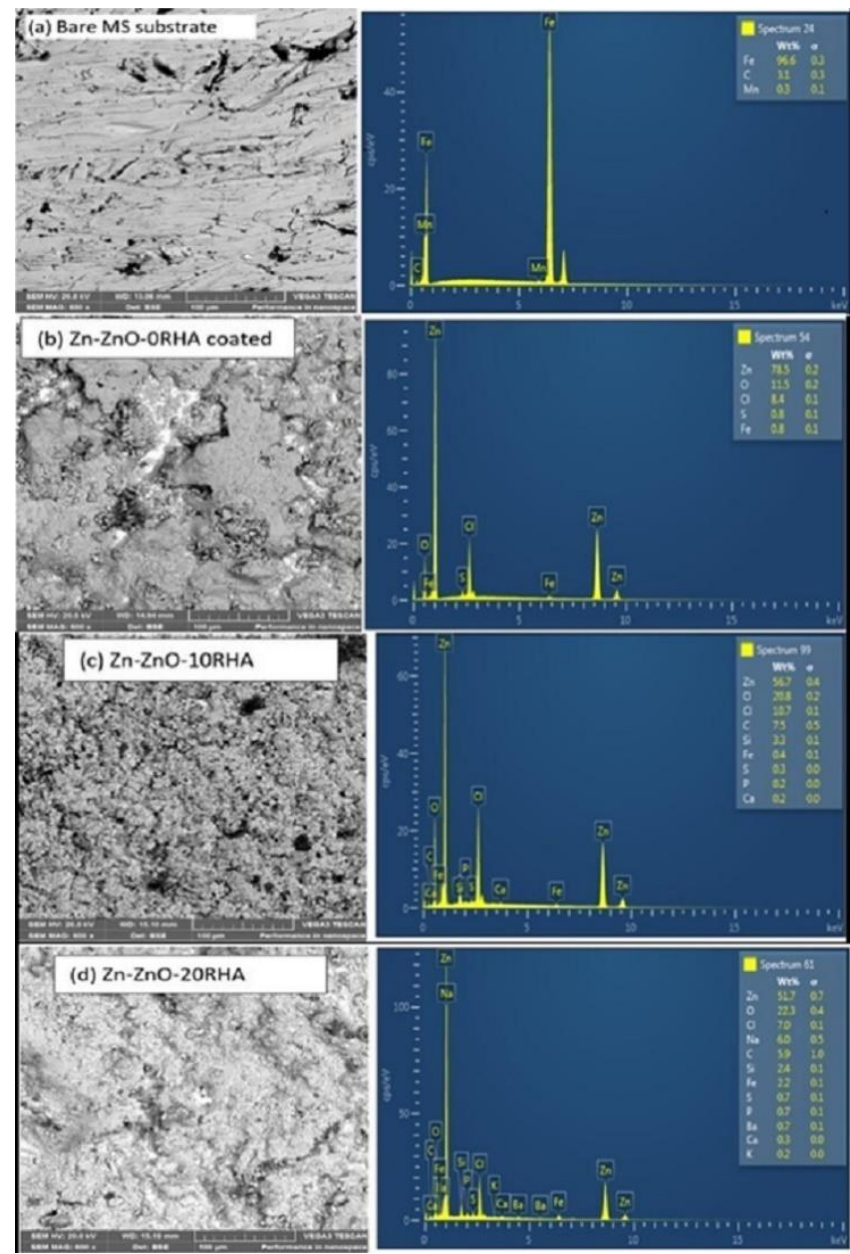

Figure 5. Surface morphology of the (a) uncoated steel substrate, (b) Zn-ZnO-0RHA, (c) Zn-ZnO-10RHA and (d) $\mathrm{Zn}-\mathrm{ZnO}-20 \mathrm{RHA}$ developed coating on mild steel substrate with EDS 


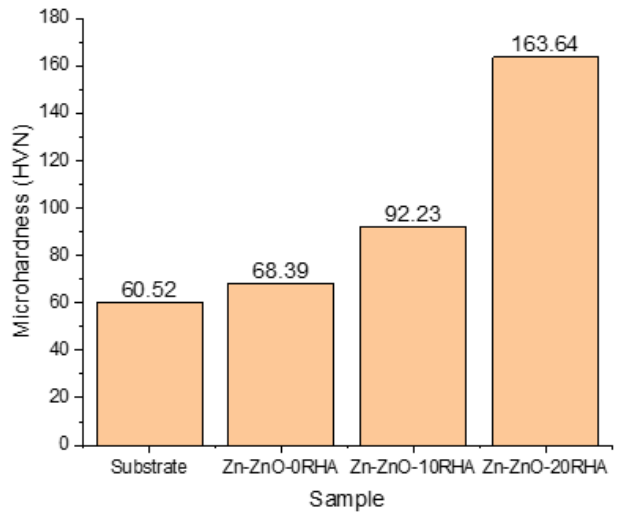

Figure 6. Microhardness of the uncoated steel substrate, Zn$\mathrm{ZnO}-0 \mathrm{RHA}, \mathrm{Zn}-\mathrm{ZnO}-10 \mathrm{RHA}$ and $\mathrm{Zn}-\mathrm{ZnO}-20 \mathrm{RHA}$ coated substrates

\subsection{Wear resistance assessment}

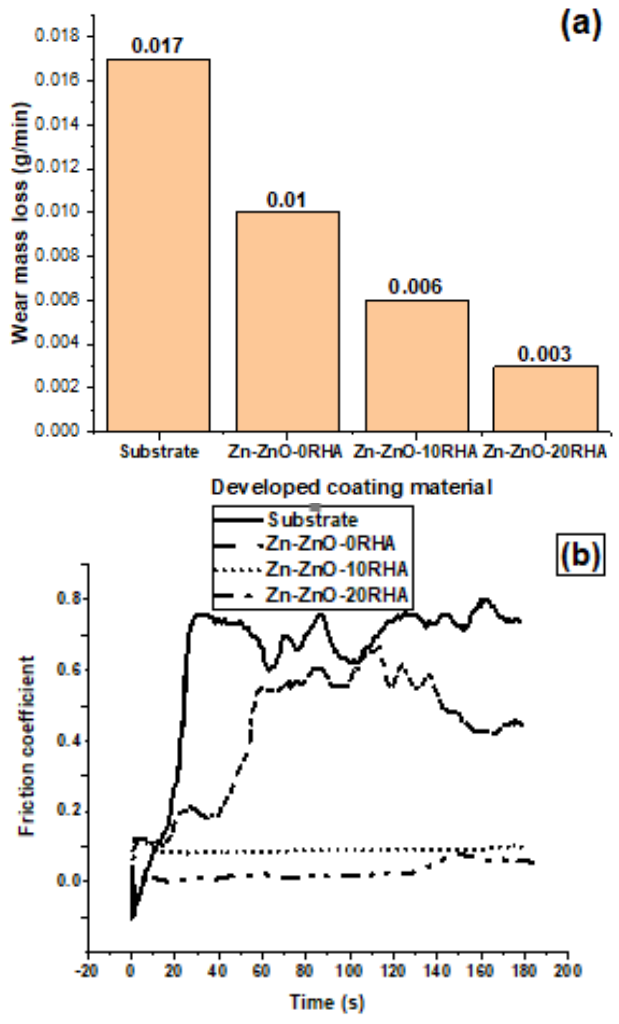

Figure 7. (a) Wear loss and (b) Range of friction coefficient assessment of the uncoated MS substrate, $\mathrm{Zn}-\mathrm{ZnO}$-0RHA,

$\mathrm{Zn}-\mathrm{ZnO}-10 \mathrm{RHA}$ and $\mathrm{Zn}-\mathrm{ZnO}-20 \mathrm{RHA}$ coated substrates

The trend of the wear loss for the developed $\mathrm{Zn}-\mathrm{ZnO}$ XRHA is a descending one relative to increased particulate loading. This is shown in Figure 7(a). It is obvious that the uncoated MS substrate had the highest wear loss value of $0.017 \mathrm{~g} / \mathrm{min}$. the introduction of coating drastically reduced the wear loss with the least wear loss of $0.0026667 \mathrm{~g} / \mathrm{mins}$ attained by the $\mathrm{Zn}-\mathrm{ZnO}-\mathrm{XRHA}$. This insight that the developed coatings have lubrication abilities in relation to the steel ball used for the wear test. This could be adjoined with the multifaceted phases in RHA. Vividly, the structural evolution of the coating strengthens adhesion potential. Thus, declining plastic deformation [26] due to the reduction in friction coefficient range as shown in Figure 7(b). The friction coefficient ranges were $0.1115-0.7068,6.82 \mathrm{E}-04-0.2169$, 9.94E-04 -0.1808 and $0.0032-0.1419$ for the substrate, $\mathrm{Zn}$ -
ZnO-0RHA, Zn-ZnO-10RHA, and Zn-ZnO-20RHA respectively. Malatji et al. observed a decrease in friction coefficient with particulate incorporation which was attributed to retard of the dislocation movement. The wear tracks are shown in Figure 8 (a) - (d).

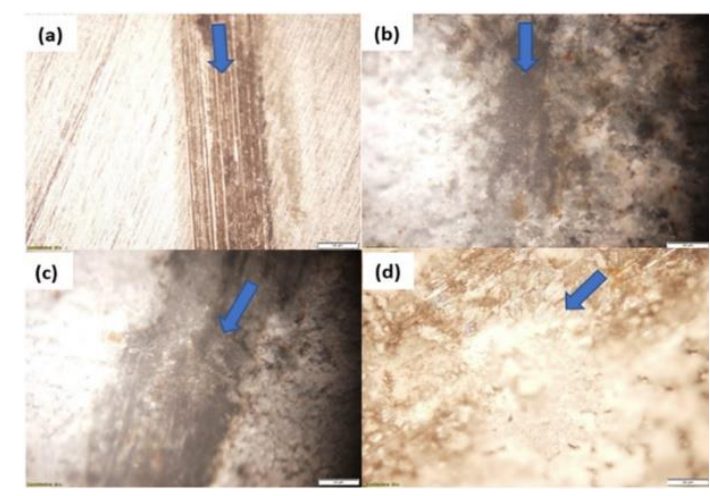

Figure 8. Wear track assessment of the uncoated MS substrate, $\mathrm{Zn}-\mathrm{ZnO}-0 \mathrm{RHA}, \mathrm{Zn}-\mathrm{ZnO}-10 \mathrm{RHA}$ and $\mathrm{Zn}-\mathrm{ZnO}$ 20RHA coated substrates

\section{CONCLUSIONS}

RHA has emerged as a complementary coating material additive for many researches on uni- and multi- phased additive incorporation. Hence, the following conclusions are drawn:

1. Successful chloride-based electrodeposition of $\mathrm{Zn}-\mathrm{ZnO}$ RHA composite coating on mild steel substrate was achieved.

2. Improved hardness was attained with successive incorporation of RHA particulate loading.

3. The emergence of hard phases was in the uniformly dispersed $\mathrm{Zn}-\mathrm{ZnO}-\mathrm{RHA}$ composite coating was machinery for self-lubrication leading to improved wear resistance.

\section{ACKNOWLEDGMENT}

The support of the staff members of the Department of Metallurgical and Materials Engineering, Faculty of Engineering, University of Nigeria, Nsukka, Enugu State, Nigeria, SERC LABORATORY, Department of Chemical, Metallurgical and Materials Engineering, Faculty of Engineering and Built Environment, Tshwane University of Technology, Pretoria, South Africa and the NEEDS financial support is highly appreciated.

\section{REFERENCES}

[1] Kumar, S., Sangwan, P., Dhankhar, R.M.V., Bidra, S. (2013). Utilization of rice husk and their ash: A review. Research Journal of Chemical and Environmental Sciences, 1(5): 126-129.

[2] Veselov, I.N., Pyshmintsev, I.Y., Laev, K.A., Zhukova, S.Y. (2011). Structure and mechanical properties of lowcarbon steel for oil and gas pipelines. Steel in Translation, 41(2): 82-86. https://doi.org/10.3103/S0967091211020197

[3] Chen, Z., Shum, K., Salagaj, T., Zhang, W., Strobl, K. 
(2010). $\mathrm{ZnO}$ thin films synthesized by chemical vapor deposition. In 2010 Long Island Systems, Applications and Technology Conference, LISAT 10. https://doi.org/10.1109/LISAT.2010.5478331

[4] Hamid, Z.A., Aal, A.A., Hassan, H.B., Shaaban, A. (2010). Process and performance of hot dip zinc coatings containing $\mathrm{ZnO}$ and $\mathrm{Ni}-\mathrm{P}$ under layers as barrier protection Applied Surface Science Process and performance of hot dip zinc coatings containing $\mathrm{ZnO}$ and $\mathrm{Ni}-\mathrm{P}$ under layers as barrier protection. Applied Surface Science, 256(13): 4166-4170 https://doi.org/10.1016/j.apsusc.2010.01.119

[5] Baptista, A., Silva, F., Porteiro, J., Míguez, J., Pinto, G. (2018). Sputtering physical vapour deposition (PVD) coatings: A critical review on process improvement andmarket trend demands. Coatings, 8(11). https://doi.org/10.3390/COATINGS8110402

[6] Offor, P.O., Ude, S.N., Whyte, G.M., Obayi, C.S., Omah, A.D., Whyt, F.U., Ezema, F.I. (2020). The influence of substrate temperature on properties of zinc sulphide thin films synthesized by chemical spray pyrolysis. Asian Journal of Basic Science \& Research (AJBSR), 2(1): 115.

[7] Offor, P.O., Okorie, B.A., Ezema, F.I., Aigbodion, V.S., Daniel-Mkpume, C.C., Omah, A.D. (2016). Synthesis and characterization of nanocrystalline zinc sulphide thin films by chemical spray pyrolysis. Journal of Alloys and Compounds, 650. https://doi.org/10.1016/j.jallcom.2015.07.169

[8] Offor, P.O., Nwanya, A.C., Omah, A.D., DanielMkpume, C.C., Maaza, M., Okorie, B.A., Ezema, F.I. (2017). Chemical spray pyrolysis deposition of zinc sulphide thin films using ethylenediaminetetraacetic acid disodium salt complex ant. Journal of Solid State Electrochemistry, $\quad 21(9)$ : $2687-2697$. https://doi.org/10.1007/s10008-017-3668-2

[9] Zhang, H., Wang, X.Y., Zheng, L.L., Jiang, X.Y. (2001). Studies of splat morphology and rapid solidification during thermal spraying. International Journal of Heat and Mass Transfer, 44(24): 4579-4592. https://doi.org/10.1016/S0017-9310(01)00109-0

[10] Beattie, S.D., Dahn, J.R. (2003). Comparison of electrodeposited copper-zinc alloys prepared individually and combinatorially. Journal of the Electrochemical Society, 150(11): C802-C806. https://doi.org/10.1149/1.1615998

[11] Fayomi, O.S.I., Oluwadare, G.A., Fakehinde, O.B., Akande, I.G., Nwachia, W., Oziegbe, U., Russell, A.J. (2019). Evolution of physical and mechanical characteristics of deposited composite coatings on A356 mild steel. International Journal of Advanced Manufacturing Technology, 103(5-8): 2621-2625. https://doi.org/10.1007/s00170-019-03714-1

[12] Ali, R., Azelee, W., Abu, W., Teck, L.K. (2010). $\mathrm{Zn} / \mathrm{ZnO} / \mathrm{TiO}_{2}$ and $\mathrm{Al} / \mathrm{Al}_{2} \mathrm{O}_{3} / \mathrm{TiO}_{2}$ photocatalysts for the degradation of cypermethrin. Modern Applied Science, 59-67.

[13] Malatji, N., Popoola, A.P.I. (2015). Electrodeposition of ternary $\mathrm{Zn}-\mathrm{Cr}_{2} \mathrm{O}_{3}-\mathrm{SiO}_{2}$ nanocomposite coating on mild steel for extended applications. International Journal of Electrochemical Science, 10(5): 3988-4003.

[14] Fayomi, O.S.I., Popoola, A.P.I., Olorunniwo, O.E. (2016). Structural and properties of $\mathrm{Zn}-\mathrm{Al}_{2} \mathrm{O}_{3}-\mathrm{SiC}$ nanocomposite coatings by direct electrolytic process.
International Journal of Advanced Manufacturing Technology, 87(1-4). https://doi.org/10.1007/s00170016-8428-4

[15] Popoola, A.P.I., Aigbodion, V.S., Fayomi, O.S.I. (2016). Anti-corrosion coating of mild steel using ternary $\mathrm{Zn}$ $\mathrm{ZnO}-\mathrm{Y}_{2} \mathrm{O}_{3}$ electro-depositon. Surface and Coatings Technology,

306. https://doi.org/10.1016/j.surfcoat.2016.05.018

[16] Fayomi, O.S.I., Popoola, A.P.I., Ige, O.O., Ayoola, A.A. (2017). Study of Particle incorporation and performance characteristic of aluminium silicate-zirconia embedded on zinc rich coatings for corrosion and wear performance. Asian Journal of Chemistry, 29(12): 2575-2581. https://doi.org/10.14233/ajchem.2017.20659

[17] Rekha, M.Y., Srivastava, C. (2019). Microstructural evolution and corrosion behavior of znni-graphene oxide composite coatings. Metallurgical and Materials Transactions $\quad$ A, 50: 5896-5913. https://doi.org/10.1007/s11661-019-05474-9

[18] Tseluikin, V.N. (2017). Electrodeposition and properties of composite coatings modified by fullerene $\mathrm{C}_{60}$. Protection of Metals and Physical Chemistry of Surfaces, 53: $278-281$. https://doi.org/10.1134/S2070205117030248

[19] Ayoola, A.A., Fayomi, O.S.I., Popoola, A.P.I., Fayomi, O.S.I. (2018). High temperature thermal treatment of Zn$10 \mathrm{Nb}_{2} \mathrm{O}_{5}-10 \mathrm{SiO}_{2}$ crystal coatings on mild steel. Cogent Engineering, $\quad 5(1)$ : https://doi.org/10.1080/23311916.2018.1540026

[20] Daniel-Mkpume, C.C. (2020). Development of Zn-ZnOClay and $\mathrm{Zn}-\mathrm{ZnO}$-Rice Husk Ash material systems for corrosion control of oil pipelines. University of Nigeria, Nsukka, Nigeria.

[21] Kumar, M., Sasikumar, C. (2014). Electrodeposition of nanostructured $\mathrm{ZnO}$ thin film: A review. American Journal of Materials Science and Engineering, 2(2): 1823. https://doi.org/10.12691/ajmse-2-2-2

[22] Srivastava, M., Grips, V.K.W., Rajam, K.S. (2007). Electrochemical deposition and tribological behaviour of $\mathrm{Ni}$ and Ni-Co metal matrix composites with $\mathrm{SiC}$ nanoparticles. Applied Surface Science, 253(8): 3814-3824. https://doi.org/10.1016/j.apsusc.2006.08.022

[23] Fayomi, O.S.I. (2015). Effect of composite particulate reinforcement on the morphology, anti-corrosion and hardness properties of fabricated $\mathrm{Zn}-\mathrm{ZnO}$ coatings. Journal of Materials and Environmental Science, 6(4): 963-968.

[24] Xu, R., Wang, J., Guo, Z., Wang, H. (2008). Effects of rare earth on microstructures and properties of Ni-W-P$\mathrm{CeO}_{2}-\mathrm{SiO}_{2}$ nano-composite coatings. Journal of Rare Earths, 26(4): 579-583. https://doi.org/10.1016/S10020721(08)60141-6

[25] Monyai, T., Fayomi, O.S.I., Popoola, A.P.I. (2016). A novel effect of solanum tuberosum/Zn-30Al-7Ti sulphate modified coating on UNS G10150 mild steel via dual-anode electrodeposition route. Portugaliae Electrochimica Acta, 34(5): 355-363. https://doi.org/10.4152/pea.201605355

[26] Malatji, N., Popoola, A.P.I., Fayomi, O.S.I., Loto, C.A. (2015). Multifaceted incorporation of $\mathrm{Zn}-\mathrm{Al}_{2} \mathrm{O}_{3} / \mathrm{Cr}_{2} \mathrm{O}_{3} /$ $\mathrm{SiO}_{2}$ nanocomposite coatings: anti-corrosion, tribological, and thermal stability. International Journal of Advanced Manufacturing Technology, 82: 1335-1341. https://doi.org/10.1007/s00170-015-7463-x 